\title{
A small drop of hope for the dry ground: introducing drip irrigation to rote island, indonesia, to convince fishermen to farm during the dry season for an alternative livelihood
}

\section{Introduction}

Located close to the dry continent of Australia, East Nusa Tenggara (ENT) is the driest and the poorest province in Indonesia. ${ }^{1,2}$ Receiving rainfalls late during the westerly monsoon, lands in the multi-island province are mostly arable only during the very short rainy season. ${ }^{3}$ This short rainy season allows the population in the drier part of the province to produce food merely enough for consumption during the beginning of the dry season and forces them to rely on alternative livelihoods for the rest of the year. Among those living in the drier part of ENT, the Rotenese are well known for their ingenuity in facing the difficulties arising from the lack and unpredictability of rain falling in their island. They tap lontar palm (Borassus flabellifer), a species of palm widespread in the island and elsewhere in the drier part of Indonsia, ${ }^{4}$ to produce sap that they drink as their carbohydrate source just as people from other parts of Indonesia eat rice, hence they are known as people who drink instead of eating their food. ${ }^{5}$ Their ingenuity does not stop just there.

They also develop a tradition to tap the vast open ocean surrounding the island and even far beyond. ${ }^{6}$ They could have learnt from the Macasan and the Buginese, who stop by in the island on their trip to fish in the Southern seas, that fishing can make much easier money than farming in dry lands. Nevertheless, most of them remain among the poorest in the island. In fact, most of income coming from fishing goes to the boss who owns the boat and equipment, and most importantly, lends them money in time of need. This short review article provides an overview of the Rotenese involvement in fishing, including in fishing in Indonesia-Australia trans-boundary waters, in connection with their dry land agriculture and lontar tapping tradition. Based this overview, we introduce drip irrigation to help women farming as a source of additional income while their husbands go fishing.

\section{Dry ground and the rotenese involvement on fishing}

Rote and the surrounding uninhibited islands are the southernmost islands of Indonesia administratively being a district known as Rote-Ndao within the province of East Nusa Tenggara (Figure 1). The majority of the population is ethnic Christian Rotinese, ${ }^{7}$ but also includes more recently settled maritime-orientated Moslem migrants from other parts of Indonesia. ${ }^{8-10}$ Households in Rote engage in various livelihoods; including lontar tapping, dry land and wetland rice farming, and a wide range of secondary crops and livestock production. ${ }^{5}$ However, farming in the island is practiced only during the short rainy season and during the rest of the year, dry ground dominates the landscape of the island, forcing residents to exploit marine resources as alternative livelihoods. ${ }^{11}$

\author{
Volume I Issue 3 - 2017 \\ Fred Benu, 'Wayan Mudita I, ${ }^{2}$ Moni \\ Muskanan ${ }^{3}$ \\ 'Faculty of Agriculture, Nusa Cendana University, Indonesia \\ ${ }^{2}$ Faculty of Economics and Business, Nusa Cendana University, \\ Indonesia \\ 3JI Adisucipto, East Nusa Tenggara, Indonesia
}

Correspondence: Moni Muskanan, Jl Adisucipto, Kota Kupang 8500 I, East Nusa Tenggara, Indonesia,

Email benufred@yahoo.com

Received: November 14, 2017 | Published: December 13, 2017

Rote island has been for centuries served as a departing ground for traditional fishermen form many parts of Indonesia, notably the Macassan, the Bajo, and the Butonese from South and Southeastern Sulawesi, during their trip south to the fish-rich waters where Indonesia Through flow transports sea water from the Pacific into the Indian Ocean. ${ }^{12}$ It is unclear whether the Rotenese have learnt fishing tradition from these sea gypsies or developed the tradition independently. The fact is now hundreds of Rotenese make the trip to an area in the Australian Exclusive Economic Zone where, according to a Memorandum of Understanding between Indonesia and Australia, Indonesian traditional fishermen are allowed to fish in an area known as $\mathrm{MoU}$ Box $^{10,11}$ (Figure 2). However, the definition of traditional fishermen is unclear and as results, many Indonesian fishermen, including Rotinese fishermen, are arrested for being accused of engaged in illegal trans-boundary fishing.

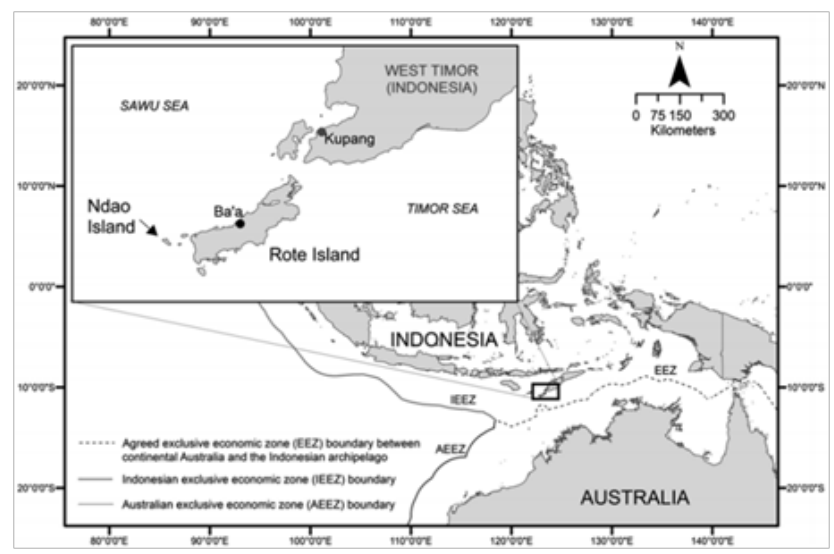

Figure I Location of Rote-Ndao District in East Nusa Tenggara Province, Indonesia. 


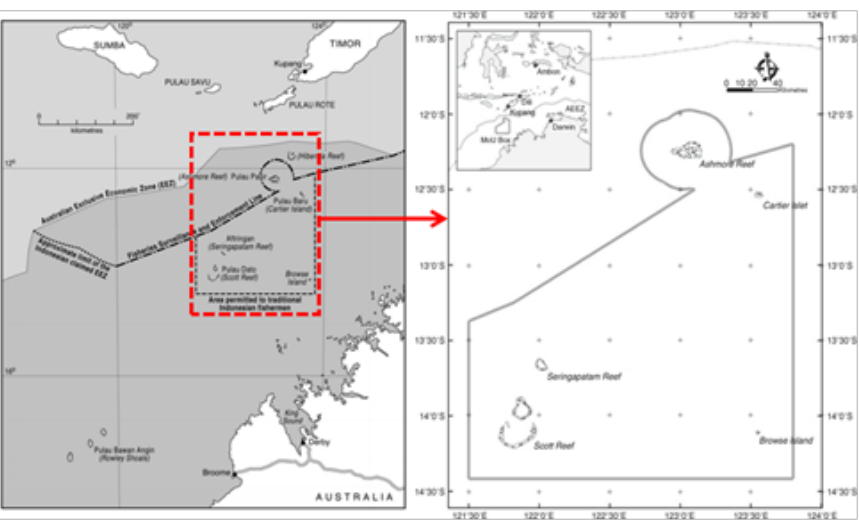

Figure $2 \mathrm{An}$ area in the Australian Exclusive Economic Zone known as MoU Box. ${ }^{31}$

The Macassan, the Bajo, and the Butonese, have been traditionally fishing in the region since $1720^{13,14}$ or even since $1640,{ }^{15}$ focusing on catching sea cucumber (trepang, edible Holothuroidea). ${ }^{16}$ However, according to Prescott et al., ${ }^{11}$ recent fishing activities also catch fish from several commercial families, namely Indian mackerel (Rastrelliger spp.), herring (Herklotsichthys spp.), sardines (Sardinella spp.), and small tunas of the family Scombridae (e.g. Auxis thazard), although in some years significant catches also include squid (Uroteuthis bartschi) and other less common species such as flying fishes (Exocetidae), halfbeaks (Hemiramphidae), needlefish (Belonidae), scads (Carangidae), fusiliers (Caesionidae), ponyfish (Leiognathidae) and occasionally marine turtles taken for consumption or sales if caught as by catch. A recent study by Benu et al. ${ }^{17}$ indicated that, despite their involvement in commercial fishing fleets, most of the studied coastal villagers live in poverty. Their involvement in trips to fish in the MoU Box is mainly by operating perahus (traditional boats) owned by bosses living either in the island or outside. In a common agreement with a boss, one third of the catch resulting from a one-week trip will go to the owner of the perahu and the fishing gear, another one third to the sponsor of the voyage, and the last one third to be divided among the captain and his crews (3-4 persons). Other Rotenese fishermen are also involved in offshore fishing inside Indonesian waters and in coastal fishing around the island. On average, they received an income of Rp 3 million a month out of fishing from April to October, but for a household with four children, the monthly cost of living is Rp 3.254 million. In many cases, the fishermen also need to return the money they borrow to cover the cost of living of their wife and children while they are away.

\section{A need for a more water-efficient irrigation system}

The dry ground dominating the landscape of Rote Island during the dry season is partially due to the island's lack of irrigation infrastructure. During the rainy season, many annual crops are cultivated in the island, including irrigated rice using conventional irrigation system. Traditional water management for agriculture does exist, called mamar system, by which a pocket of remnant forest is conserved around a spring or any other permanent stream to ensure that the water can be used to irrigate, or more precisely, to supply water to the surrounding small pocket of cultivated land, ${ }^{18}$ (Figure 3 ). However, most of such springs or streams dry up toward the end of the dry season. High evaporation caused by high temperature and strong winds as well as karstic geology of the island limit the amount of water available to irrigate areas further away. In addition, such springs and streams are not evenly distributed throughout the island.

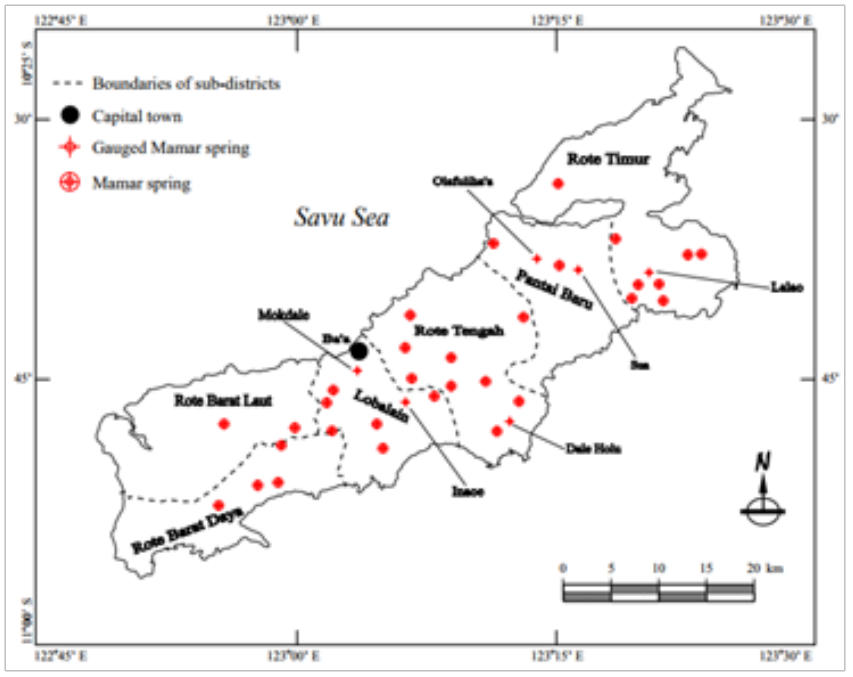

Figure 3 The distribution of mamar spring and gauged mamar spring in Rote Island Klaas. ${ }^{18}$

In order to use the available water from such springs or streams, efforts to use the available water more efficiently are clearly needed. Such efforts can be achieved by either improving the technical efficiency or the economic efficiency of water productivity. ${ }^{19}$ For farming in a hot, semi-arid karstic dry land such as in Rote Island, drip irrigation is an alternative available for this purpose. ${ }^{19-22}$ Drip irrigation systems distribute water through an either above ground or underground network of pipes, hose, valves, and emitters allowing water to drip slowly and directly into the root zone and at the same time reducing evaporation (Figure 4). Drip irrigation systems have been in use as a new initiative to alleviate hunger and poverty among small-hoder farmer in many dry areas Postel et al. 2001, including to tap rainwater for farming in water-scarse regions. ${ }^{23-26}$

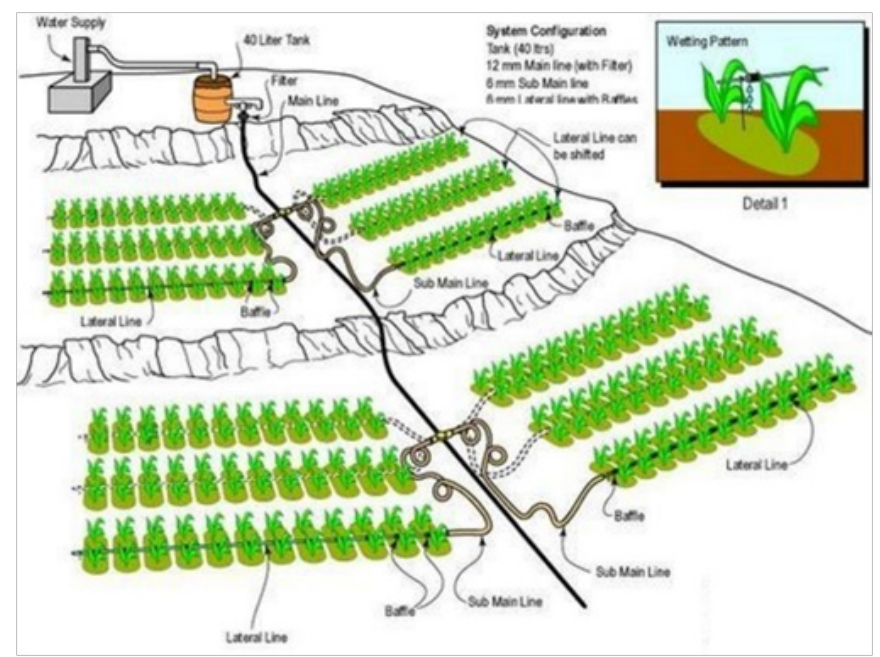

Figure $4 \mathrm{~A}$ typical layout of an above ground drip irrigation system.

\section{Introducing drip irrigation farming: a case study}

As a follow up of a research project on the livelihoods of Rotenese fishermen involved in trans-boundary fising, Benu ${ }^{17}$ introduced 
drip irrigation as an alternative livelihood. For this purpose, a drip irrigation system consisting of a solar-cell powered pump, an elevated water storage tank, a main polyethilene distribution pipe, distribution valves, and lateral hoses was constructed in the village of Daiama in Landu Leko sub-district (Figure 5). The construction of the drip irrigation system was followed with system testing and a discussion on the operation and maintenance of the system for growing highpriced vegetable crops consisting of chillies (Capsicum frutescens), tomatoes (Lycopersicon esculentum), and watermelon (Citrulus lanatus) (Figure 6). The cost for buying the pump and water tank and for constracting the tank flatform was USD 1, 500 and for intalling the dripping system was USD 400 per hectare. Based on a trial carried out at the dry land farming research unit of Nusa Cendana University, the variable cost for farming one hectar chillies, tomatoes, and watermelon under traditional irrigation was USD 566, 597, and 587, respectively, and under drip irrigation was USD 154, 185, and 175, respectively (Table 1). (Table 1) Show that the significant reduction in water consumption contributes to much lower variable costs under drip irrigation than under traditional irrigation for each crop. This is possible because the drip irrigation system delivers water right to the roots of the crops, thus ensuring that there is no waste of water. In addition, because fertilizers were applied together with the water, ${ }^{28,29}$ the drip irrigation system also saved on labor costs, allowing shrinkage of variable cost by more than $100 \%$. Gross margin analysis similar to that by Benu and Mudita ${ }^{30}$ was used as an approach to convince fishermen to farm high-valled horticultural crops using a drip irrigation system. As shown in (Table 2), the gross margin for chillies, tomatoes, and watermelon under drip irrigation doubles the gross margin for each crop under traditional cultivation.

The higher gross margin under the drip irrigation than under the traditional irrigation was due to the lower variable cost and at the same time to the higher revenue. This is possible because according to Dhawan, ${ }^{28}$ drip irrigation supplies water more regularly to the crop and direct to its root system. During the discussion, the fishermen raised a number of issues related to the cost of system contruction, technical maintenance know-how, and farming credits. Issues such as inadequate farmers' capacity to adopt the system, poor agricultural practices, and absence of rural micro-credit providers needed to pay for higher infrastructure investment cost are common wherever a drip irrigation system is introduced. ${ }^{29,31}$ Such issues need to be addressed separately. What this project shows is that an alternative is available for the fishermen in Rote Island to obtain a better income than that they obtain from illegal fishing. ${ }^{32}$

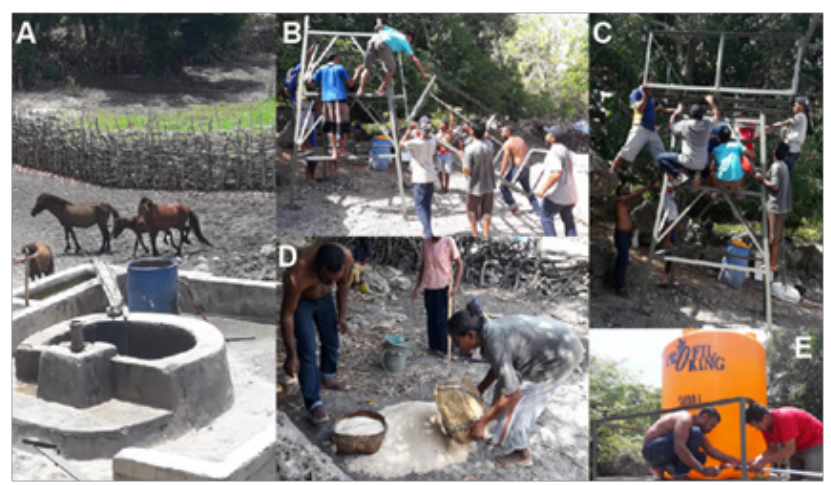

Figure 5 Construction of the tank flatform, (A) Open dug-well as the source of water, (B) Raising the tank flatform, (C) Placing the tank flatform above it supporting legs, (D) Mixing sand with cement to anchor the supporting legs of the tank flatform above ground, and E: Installing the polyethilene main distribution pipe into the tank.

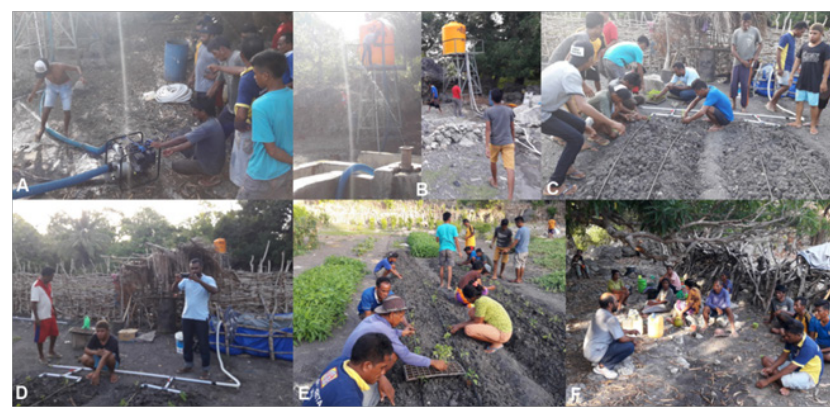

Figure 6 Testing water flow, planting the beds, and discussing system and crop maintenance. (A) Testing the pump, (B) Testing the flow of water to the tank, (C) Placing the main and sub-main distribution pipes and lateral hoses, (D) Testing the flow of water to the lateral hoses, (E) Planting chili seedlings, and (F) Discussing system and crop maintenance.

Table I Variable costs for farming I ha chillies, tomatoes, and watermelon under traditional and drip irrigations

\begin{tabular}{|c|c|c|c|c|c|c|}
\hline \multirow[t]{2}{*}{ Item } & \multicolumn{3}{|c|}{ Traditional irrigation } & \multicolumn{3}{|c|}{ Drip irrigation } \\
\hline & Quantity & Cost (USD) & Total cost (USD) & Quantity & Cost (USD) & Total cost (USD) \\
\hline Water consumption $\left(\mathrm{m}^{3}\right)$ & 900 & 0.08 & 73 & 450 & 0.08 & 36 \\
\hline Fuel (L) & 0 & 0 & 0 & 15 & 0.77 & 12 \\
\hline Labour (USD) & 15 & 30.77 & 462 & 3 & 30.77 & 92 \\
\hline \multicolumn{7}{|l|}{ Seeds } \\
\hline Chillies (g) & 4 & 1.54 & 6 & 4 & 1.54 & 6 \\
\hline Tomatoes (g) & 6 & 6.15 & 37 & 6 & 6.15 & 37 \\
\hline Watermelon (g) & 10 & 2.69 & 27 & 10 & 2.69 & 27 \\
\hline Fertilizer (kg) & 3 & 8.46 & 25 & 1 & 8.46 & 8 \\
\hline \multicolumn{7}{|l|}{ Total variable cost } \\
\hline Chillies & & & 566 & & & 154 \\
\hline Tomatoes & & & 597 & & & 185 \\
\hline Watermelon & & & 587 & & & 175 \\
\hline
\end{tabular}

Source: Analysis of field data (2017). 
Table 2 Gross margins of farming I ha chillies, tomatoes, and watermelon under traditional and drip irrigations

\begin{tabular}{lllllll}
\hline \multirow{2}{*}{ Item } & \multicolumn{5}{l}{ Traditional irrigation } \\
\cline { 2 - 6 } & Quantity & Price (USD) & Total (USD) & Quantity & Price (USD) & Total (USD) \\
\hline Revenue & & & & \\
\hline Chilies $(\mathrm{kg})$ & 830 & 1.92 & 1,597 & 1,186 & 1.92 & 2,281 \\
Tomatoes (kg) & 3,259 & 0.92 & 3,008 & 4,656 & 0.92 & 4,298 \\
Watermelon (kg) & 6,395 & 0.38 & 2,459 & 9,135 & 0.38 & 3,513 \\
\hline Total variable cost & & & & & \\
\hline Chillies & & 566 & & 154 \\
Tomatoes & & 597 & & 185 \\
Watermelon & & 587 & & 175 \\
\hline Gross margin (GM) & & & & & \\
\hline Chillies & & 1,031 & & 2,127 \\
Tomatoes & & 2,411 & & 4,113 \\
Watermelon & & 1,872 & & 3,338 \\
\hline
\end{tabular}

Source:Analysis of field data (2017).

\section{Conclusion}

The Rotenese have been for centuries involved in fishing in the Indonesia-Australia trans boundary waters. Unfortunately, because most of the revenue generated from the Endeavour goes to the owner of the boat and the fishing gear who also fund the fishing trip, the income they bring home is not even enough to pay for the monthly cost of living of their family. As an alternative source of income, a simple drip irrigation system was constructed with the help of members of the local community to irrigate chillies, tomatoes, and watermelon. The cost for buying the pump and water tank and for constricting the tank flat form was USD 1,500 and for intalling the dripping system was USD 400 per hectare.

Based on a trial carried out at the dry land farming research unit of Nusa Cendana University, the variable cost for farming one hector chillies, tomatoes, and watermelon under traditional irrigation was USD 566, 597, and 587, respectively, and under drip irrigation was USD 154, 185, and 175, respectively. The gross margin of planting the same crops using drip irrigation was USD 2127, 4113, and 3338, respectively, whereas using the traditional irrigation was USD 1031, 2411 , and 1872, respectively. A much higher gross margin could be expected from drip than from traditional irrigation, but a number of issues need to be addressed to convince fishermen in Rote Island to adopt the introduced alternative livelihood.

\section{Acknowledgments}

We thank members of the Undana-Grifith University collaborative research project, Paul King, August Nalle, and Remi L. Natonis, for allowing us to use part of the research data and photographs to prepare this review article.

\section{Conflict of interest}

The authors whose names are listed immediately below certify that they have no affiliation with or involvement in any organization or entity with any financial interest (such as honoraria; educational grants; participation in speaks' bureaus; membership, employment, consultancies, stock ownership, or other equity interest; and expect testimony or patent-licensing arrangements), or non-financial interest ( such as personal or professional relationships, affiliations, knowledge or beliefs) in the subject matter or materials discussed in the manuscript.

\section{References}

1. Cole S. Tourism, Culture and Development: Hopes, Dreams and Realities in Eastern Indonesia. Clevedon, Buffalo, Toronto: Channel View Publications, Canada; 2008.

2. Mboi N. Health and Poverty: A Look at Eastern Indonesia. In: Barlow C, et al, editors. Indonesia Assessment 1995: Development in Eastern Indonesia. Canberra \& Singapore: Research School of Pacific and Asian Studies, ANU, and Institute of Southeast Asian Studies, Singapore; 1995.

3. Monk KA, Fretes YD, Reksodiharjo Lilley G. The ecology of Nusa Tenggara and Maluku. Periplus ed, USA; 1997. p. 1-966.

4. Morton JF. Notes on distribution, propagation, and products of Borassus Palms (Arecaceae). Economic Botany. 1988;42(3):420-441.

5. Fox JJ. Harvest of the palm. Ecological change in eastern Indonesia. USA: Harvard University Press; 1977. p. 1-290.

6. Campbell BC, Wilson B. Crime or Tradition? Indonesians in Australia's Northern Waters. Maritime Studies. 1993;1993(72):10-13.

7. SIL International. Ethnologue: Languages of the World. Diambil 11 November 2017, dari, USA; 2017.

8. Carnegie M. Development prospects in Eastern Indonesia: Learning from Oelua's diverse economy. Asia Pacific Viewpoint. 2008;49(3):354-369.

9. Carnegie M. Sailing-Trading Livelihoods in Southeastern Indonesia: Adapting to Change. Asian Journal of Social Science. 2014;41(6):543579

10. Stacey N. Boats to Burn: Bajo Fishing Activity in the Australian Fishing Zone. Canberra, Australia: ANU Press; 2007. p. 1-242.

11. Prescott J, Riwu J, Steenbergen DJ, et al. Governance and Governability: The Small-Scale Purse Seine Fishery in Pulau Rote, Eastern Indonesia. In: Interactive Governance for Small-Scale Fisheries, Springer, Cham, Europe; 2015. p. 61-84. 
12. Gordon A. Oceanography of the Indonesian Seas. 2005;18(4):14-27.

13. Macknight CC. The Voyage to Marege': Macassan Trepangers in Northern Australia. Carlton: Melbourne University Press, Australia; 1976. p. 1-175.

14. Macknight CC. Macassans and the Aboriginal Past. Archaeology in Oceania. 1986;21(1):69-75.

15. Ganter R. Muslim Australians: the deep histories of contact. Journal of Australian Studies. 2008;32(4):481-492.

16. Clark M, May SK. Macassan History and Heritage: Journeys, Encounters and Influences. Canberra, editor. Australia: ANU E Press; 2013.

17. Benu Fred Lukas, King P, Nalle A, et al. The Economic Livelihoods of Traditional Fishermen in Rote Island in Relation to the Activity of Illegal Fishing in Trans-boundary Waters of Indonesia and Australia. Nusa Cendana University, Kupang, Indonesia; 2017

18. Klaas D. Indigenous Water Management: Sustainable water conservation strategies in karstic dominated area in Rote Island, NTT Province, Indonesia. Monash University, Australia; 2008. p. 1-190.

19. Playán E, Mateos L. Modernization and optimization of irrigation systems to increase water productivity. Agricultural Water Management. 2006;80(1):100-116.

20. Deng XP, Shan L, Zhang H, et al. Improving agricultural water use efficiency in arid and semiarid areas of China. Agricultural Water Management. 2006;80(1-3):23-40.

21. Howell TA. Enhancing Water Use Efficiency in Irrigated Agriculture. Agronomy Journal. 2001;93(2):281-289.

22. Pereira LS, Oweis T, Zairi A. Irrigation management under water scarcity. Agricultural Water Management. 2002;57(3):175-206.

23. Biazin B, Sterk G, Temesgen M, et al. Rainwater harvesting and management in rain fed agricultural systems in sub-Saharan Africa-A review. Physics and Chemistry of the Earth, Parts A/B/C. 2012;(4748):139-151.
24. Burney J, Woltering L, Burke M, et al. Solar-powered drip irrigation enhances food security in the Sudano-Sahel. Proceedings of the National Academy of Sciences. 2010;107(5):1848-1853.

25. Rockström J, Karlberg L, Wani SP, et al. Managing water in rain fed agriculture-The need for a paradigm shift. Agricultural Water Management. 2010;97(4):543-550.

26. Rockström J, Barron J, Fox P. Rainwater management for increased productivity among small-holder farmers in drought prone environments. Physics and Chemistry of the Earth, Parts A/B/C. 2002;27(11-12):949959.

27. Dhawan BD. Technological Change in Indian Irrigated Agriculture: (a Study of Water Saving Methods). Ajay Verma for Commonwealth Publishers, USA; 2002. p. 1-330.

28. Sijali IV. DRIP IRRIGATION: Options for smallholder farmers in eastern and southern Africa. Nairobi, Kenya: Regional Land Management Unit, Kenya; 2001. p. 1-60.

29. Benu FL, Mudita IW. Money matters for subsistence farmers: Provision of a low-rate credit scheme by a local bank allowed mungbean farmers to adopt improved cultivation practices. Net Journal of Agricultural Science. 2017;5(2):71-78.

30. Kulecho IK, Weatherhead EK. Reasons for smallholder farmers discontinuing with low-cost micro-irrigation: A case study from Kenya. Irrigation and Drainage Systems. 2005;19(2):179-188.

31. Fox JJ, Sen S. A study of socio-economic issues facing traditional Indonesian fishers who access the MOU Box. Canberra, Australia: Environment Australia, Australia; 2002. p. 1-64. 